\title{
Abbreviations
}

AKEL Progressive Party of Working People Cypriot Communist Party

ATGWU Amalgamated Transport and General Workers Union

BCP British Communist Party

CIA Central Intelligence Agency

CPGB Communist Party of Great Britain

CPI Communist Party of Ireland

CPNI Communist Party of Northern Ireland

CYM Connolly Youth Movement

DFA Department of Foreign Affairs

DUP Democratic Unionist Party

EEC European Economic Community

EOKA Ethniki Organosis Kyprion Agoniston (National Organisation of Cypriot Fighters)

ESB Electricity Supply Board

ETA Euskadi Ta Askatasuna Basque Homeland and Freedom

FBI Federal Bureau of Investigation

FCO Foreign and Commonwealth Office

FTA Free Trade Agreement

GAA Gaelic Athletic Association

GHQ General Headquarters Staff

GOC General Officer Commanding

GPO General Post Office

HA Home Affairs

ICO Irish Communist Organisation

ICTU Irish Congress of Trade Unions

IRA Irish Republican Army

IRPB Irish Republican Publicity Bureau

ITA Irish Telephonists Association

ITGWU Irish Transport and General Workers Union

IWL Irish Workers League

IWP Irish Workers Party 


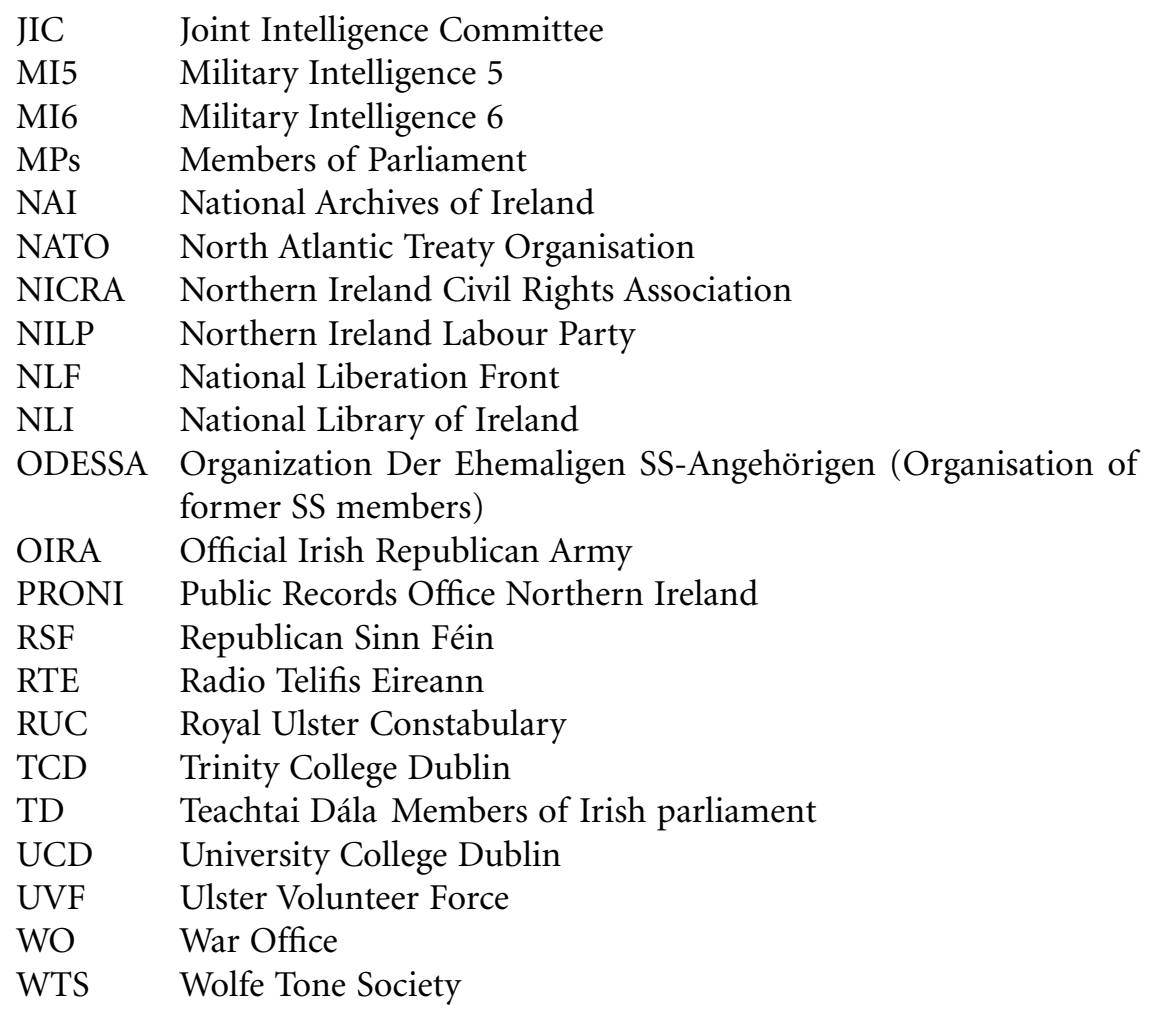

\section{Publisher's note}

Mr Anthony Coughlan wishes to state that he has never been a member either of the British or the Irish Communist Parties and that any statement or implication to the contrary contained herein is untrue. 